\title{
ORIGIN AND EFFECTS OF ANTHROPOGENIC FLASH FLOODS ON RIVERS OF HOLY CROSS MTS. REGION (POLAND) IN 20th c.
}

DOI: https://doi.org/10.18509/AGB.2019.10

UDC: $551.432 .46: 556.512]: 627.5(438)$

\section{Tomasz Kalicki, Paweł Przepióra, Piotr Kusztal}

\author{
Institute of Geography, Jan Kochanowski University in Kielce, Poland \\ corresponding author: tomaszkalicki@ymail.com
}

submitted: 24.04 .2018
accepted: 01.07 .2018
published: 18.01 .2019

\begin{abstract}
In the 20th c., after the disappearance of the system of small retention (number of artificial ponds, channels etc.) due to economic changes, on the rivers (Kamionka, Czarna Konecka) appeared events previously unknown during the whole Holocene. There are catastrophic flash floods caused by hydrotechnical damage. Geomorphological effects of these floods exceed many times the effects of secular processes.
\end{abstract}

Keywords: Holy Cross Mts., river valleys, human impact, flash floods

\section{INTRODUCTION}

The research area is located in the northern part of the Holy Cross Mountain region (central Poland) (Fig. 1). This region is characterized by large industrialization (mining and metallurgy), which started in the Middle Ages (the Old Polish and later the Central Industrial District) [1], [2], [3], [4].

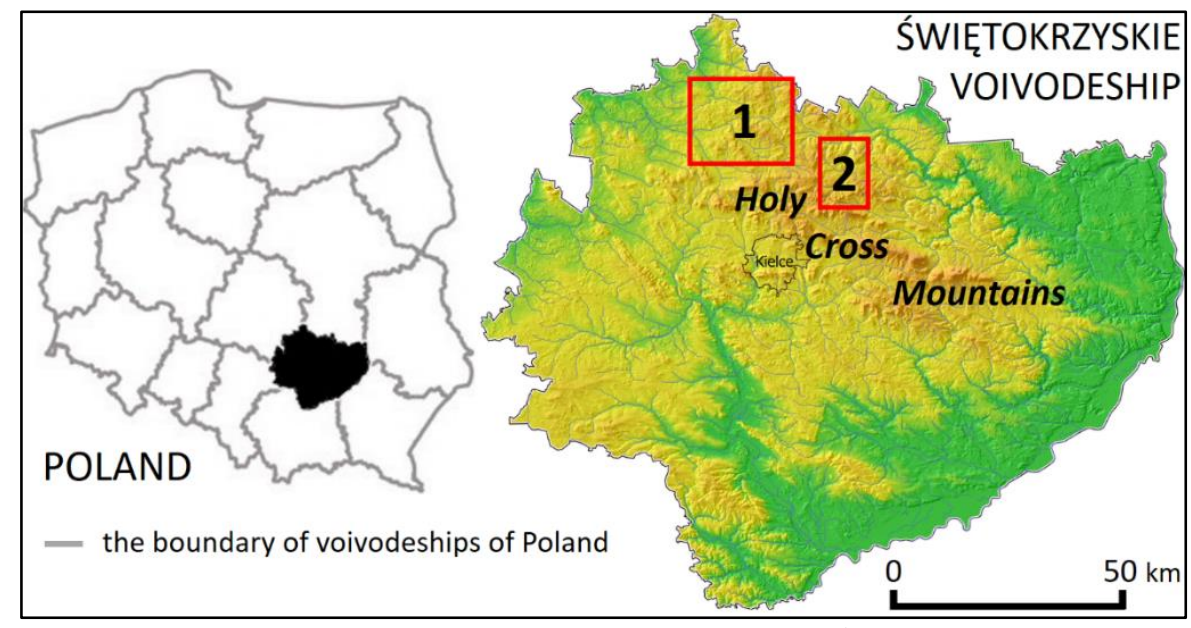

Figure 1. Location of study basins ${ }^{1}$

1 - Czarna Konecka river basin, 2 - Kamionka river basin

The iron ore resource base and water power allowed for the development of many smaller towns, where forges, smelters, and water wheel mills were functioning. This has resulted in the creation of numerous ponds, riverbed regulations and the construction of channels in order to provide sufficient energy. At the turn of the $19^{\text {th }}$ and $20^{\text {th }}$ century, the forges activity, and in the middle of the $20^{\text {th }}$ century water mills were finally stopped. Some ponds were drained and their infrastructure destroyed, while others changed their functions to retention and recreation [5].

\footnotetext{
${ }^{1}$ Digital Elevation Model (Archives UJK)
} 


\section{METHODS}

The research was interdisciplinary. Informations from archival sources (cartographic, historical) were verified in the field. Grain size of very coarse alluvia of bars was investigated in the field by the Wolman's method [6], where the size of clasts

\section{RESULTS}

While the anthropogenic small retention system from the Middle Ages had a beneficial effect on the regulation and rate of water circulation in the catchments, in the $20^{\text {th }}$ century the deteriorating technical infrastructure was conducive to the catastrophic events formation not previously occurred in the whole Holocene. In the flood periods, break in the shafts and dams, resulting in situated on the measurement lines is determined every fixed number of meters or centimeters. TL date [7] was conducted in the Scientific-Didactic Laboratory of the Institute of Geography of Jan Kochanowski University in Kielce.

rapid drainage of the ponds lead to create the flash floods downstream from the reservoirs. This kind of event took place at Czarna Konecka river in 1903 (Wąglów), the 30s (Sielpia Wielka), 1939 (Wąsosz, Janów), the 70s (Małachów), 1976 (Janów), 1993 (Małachów), 1994 (Janów), 1997 (Janów, Małachów) (Fig. 2) and at Kamionka river in 1939 (Rejów) and 1974 (Suchedniów) [8].

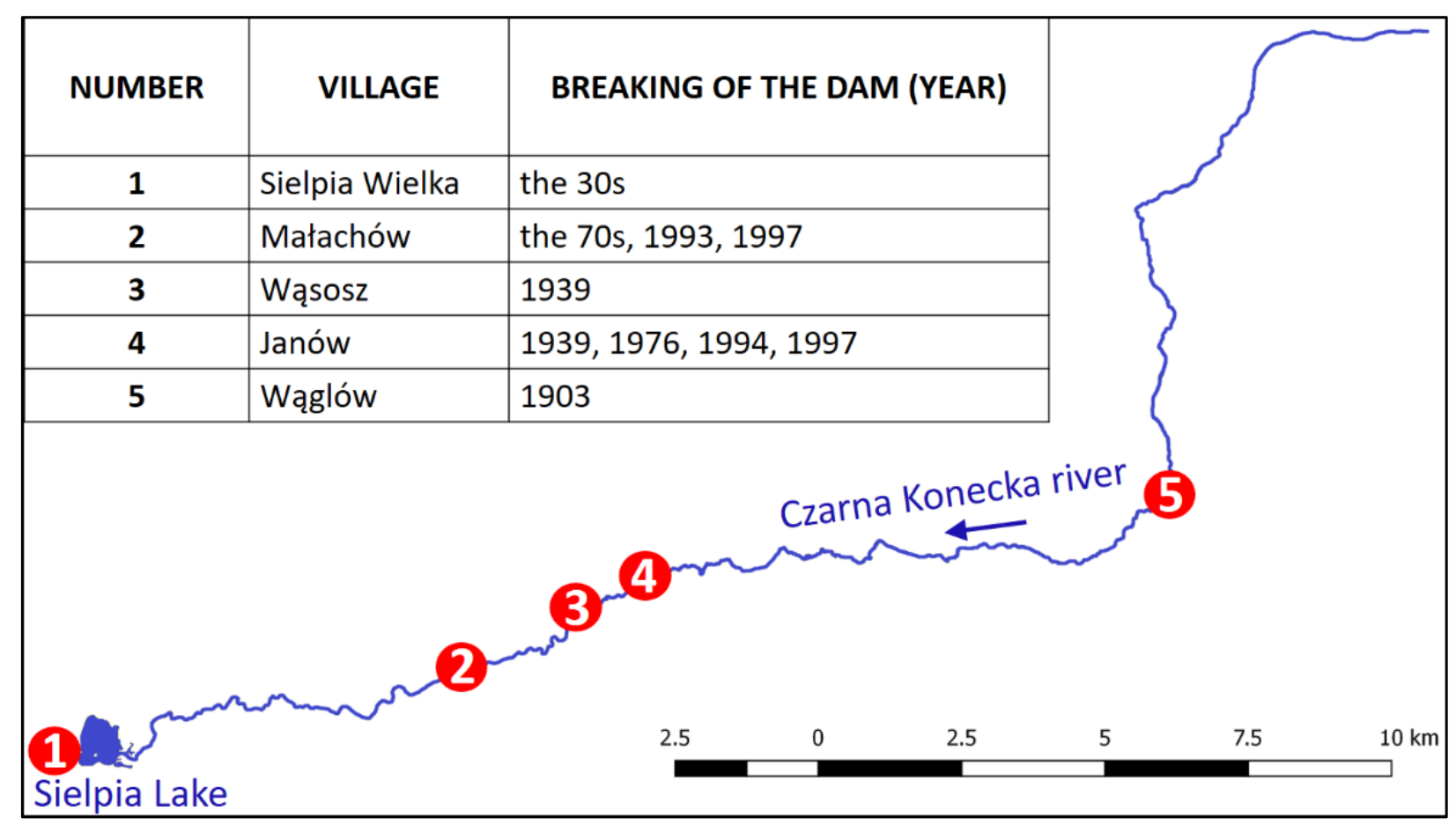

Figure 2. Anthropogenic flash floods in the Upper Czarna Konecka river valley caused by break of artificial dams [8]

The geomorphological effects of these flash floods were very large, even bigger than effects of secular processes. In Kamionka valley downstream of Suchedniów reservoir, where in 1974 took place a break of the dam just after finished the construction work, in regulated riverbed accumulate large concrete elements of dam and embankments and even a $1 \mathrm{~m}$ in diameter sandstone boulder (Fig. 3) [9]. In Czarna Konecka valley at Wąsosz Stara Wieś, few hundred meters downstream of the broken dam, was accumulated very coarse channel sediments (pebbles, gravels and sands) mixed with the slags as a remain of the forge activity (Fig. 4). The thickness of this cut-fill within the upper floodplain reaches $2 \mathrm{~m}$, while on the lower step of it is about $30 \mathrm{~cm}$ thick layer of these sediments covered older alluvium [10]. Alluvial bodies or layers of such coarse alluvia are not known from the older cut-fills of the Holocene floodplain [11]. Repeated catastrophic discharges and increased erosion after hydrotechnical failures caused incising and transformation of the riverbed (Fig. 5), floodplain (Fig. 6) and silting of the reservoir at Sielpia Wielka (Fig. 2, 7, 8) [8]. 


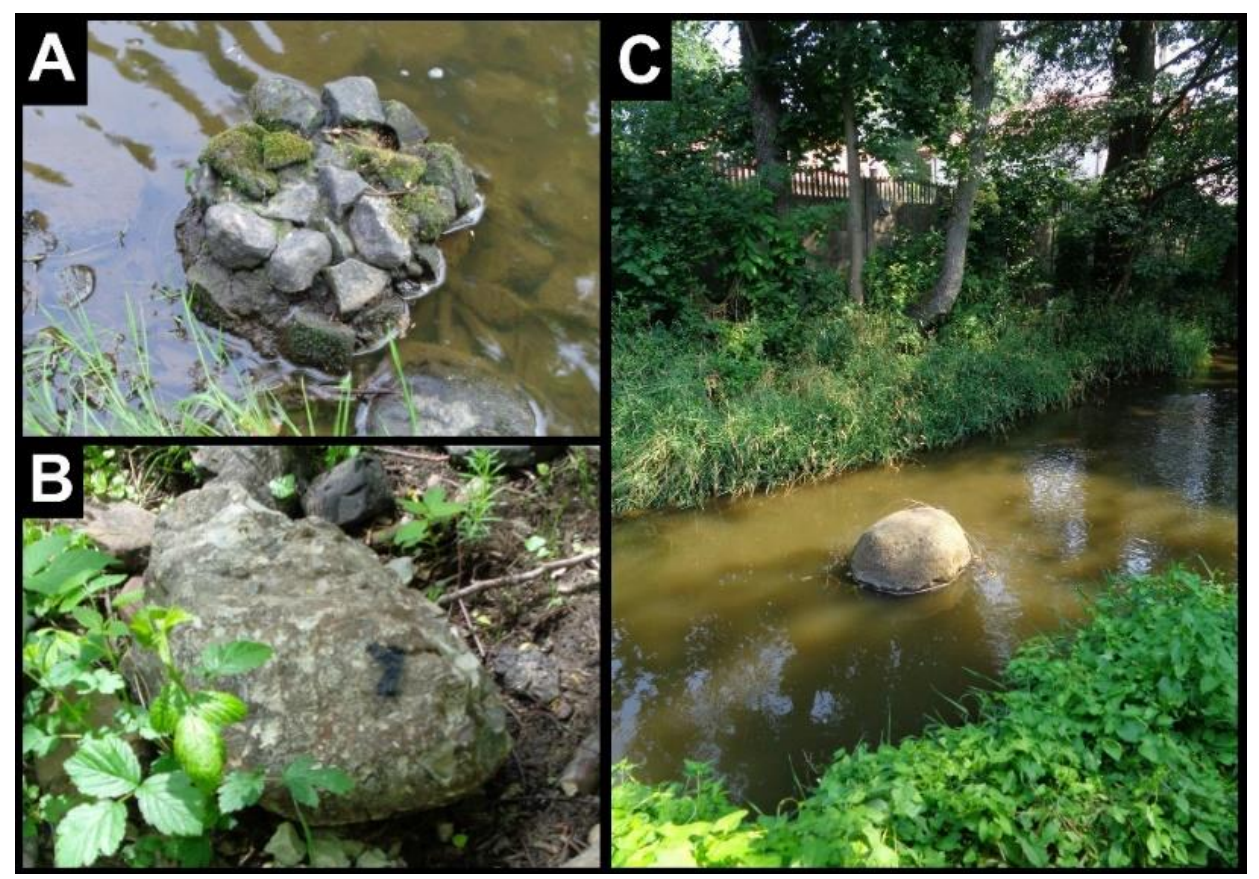

Figure 3. Traces of the flood from 1974 in the Kamionka riverbed downstream of the Suchedniów Lake dam: concrete fragments of a broken dam (A, B) and sandstone pebble with diameter about $1 \mathrm{~m}(\mathrm{C})$ transported by a flood wave (photo 2014) [8]

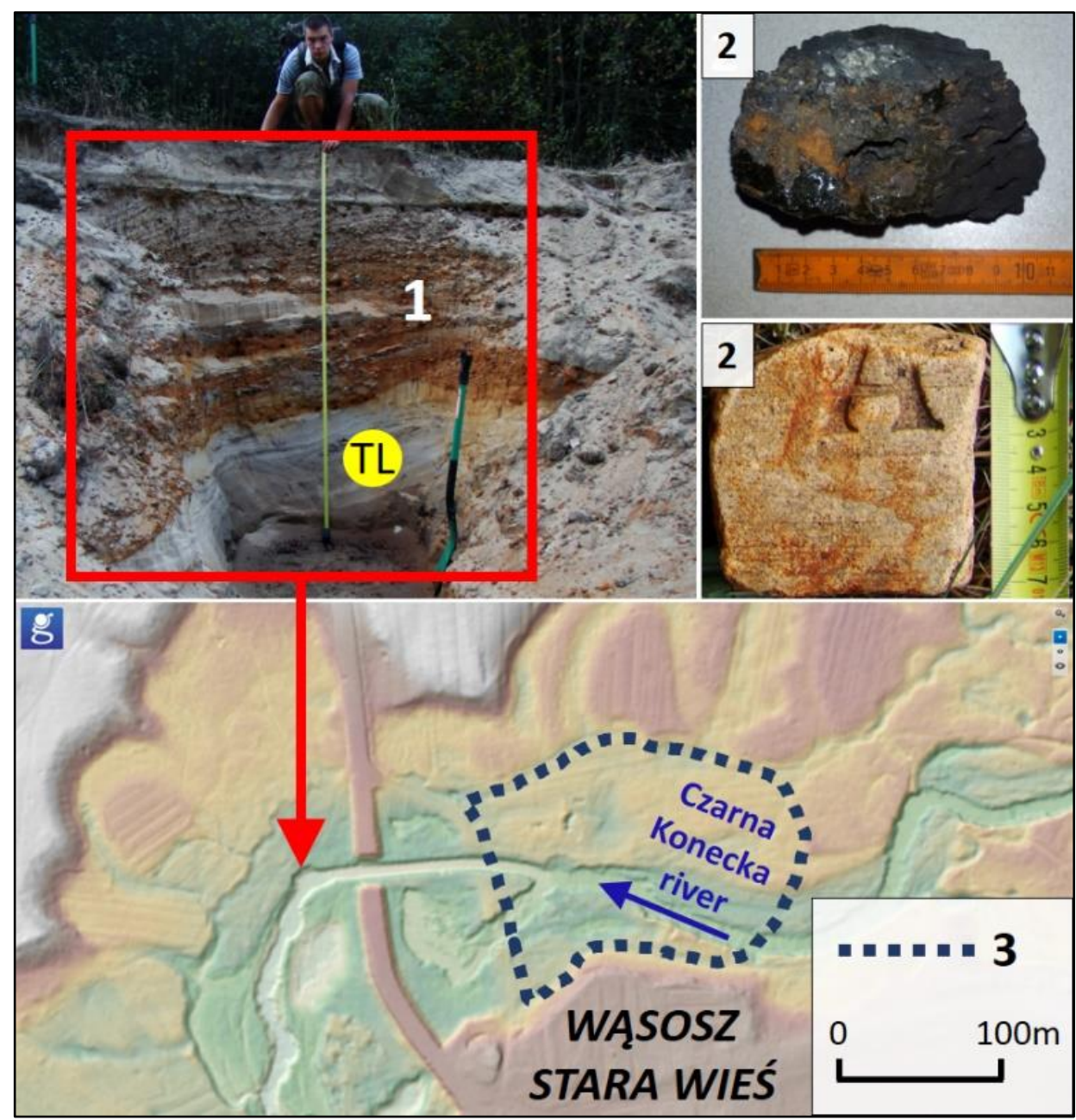

Figure 4. Cut-fill of very coarse deposits of flash flood (1) with artifacts (2) on flood plain from $20^{\text {th }} \mathrm{c}$. (TL - present-day) downstream of the former pond (3) at Wąsosz Stara Wieś ${ }^{2}$ (photo 2016) [8] 

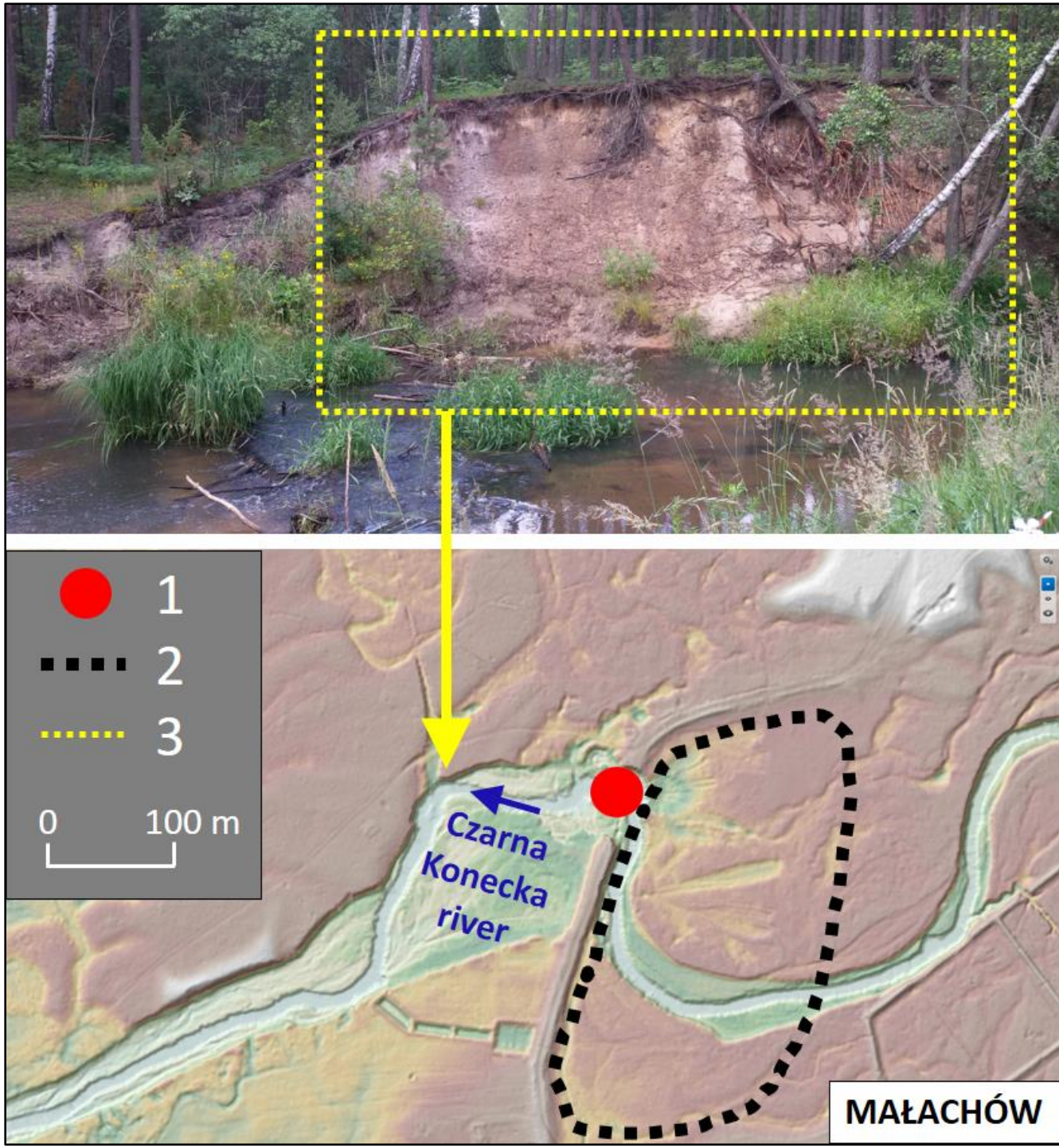

Figure 5. Upper Czarna Konecka river valley at Małachów $^{2}$ (photo 2017) [8] 1 - destroyed dam, 2 - former pond, 3 - erosional river bank cut by anthropogenic flash flood and hydrological changes after the dam break and pond disappearance

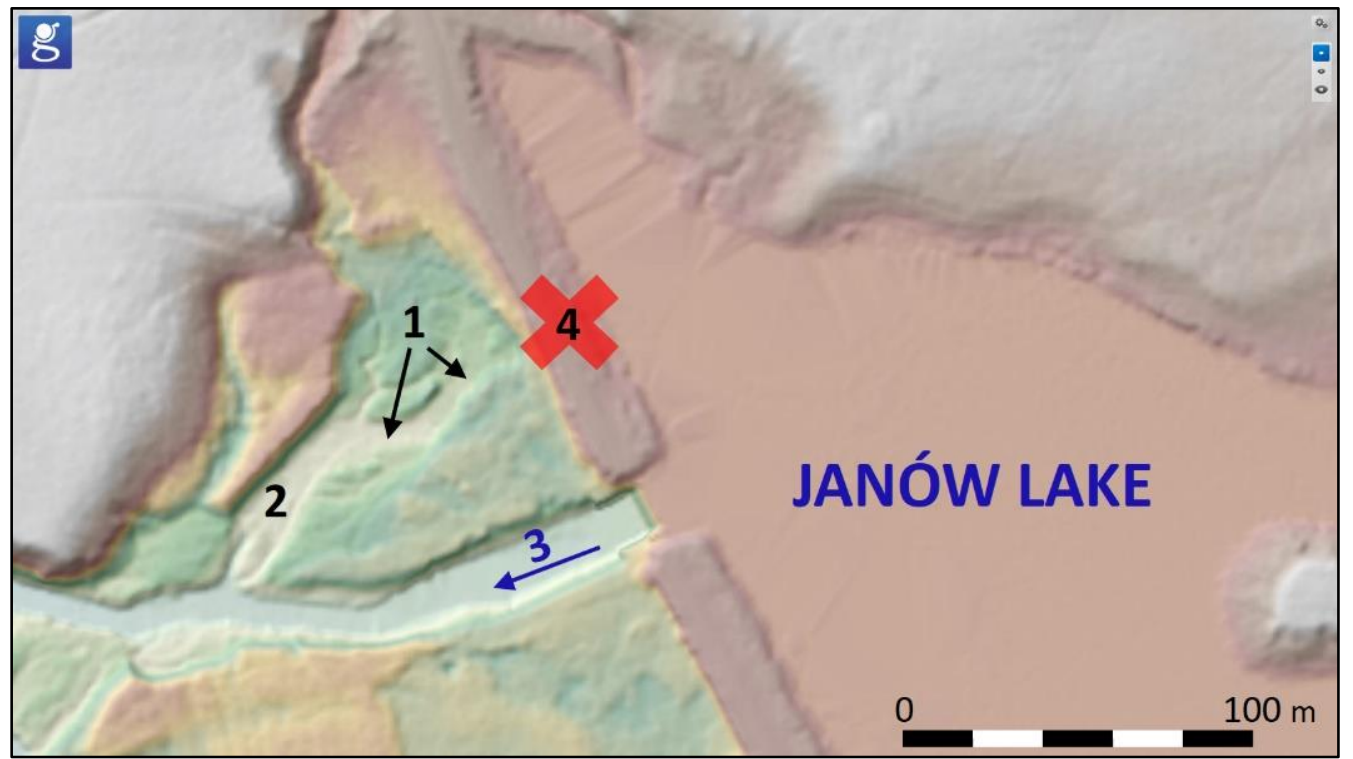

Figure 6. Erosional channels $(1,2)$ on upper Czarna Konecka flood plain resulting from dam break and rapid drainage of pond at Janów ${ }^{2}$ (pers. communications Paweł Kusztal) [8]

1 - flood's channel, 2 - transformed valley of unnamed tributary, 3 - present-day Czarna Konecka river, 4 - place of breaking the dam in 1994 

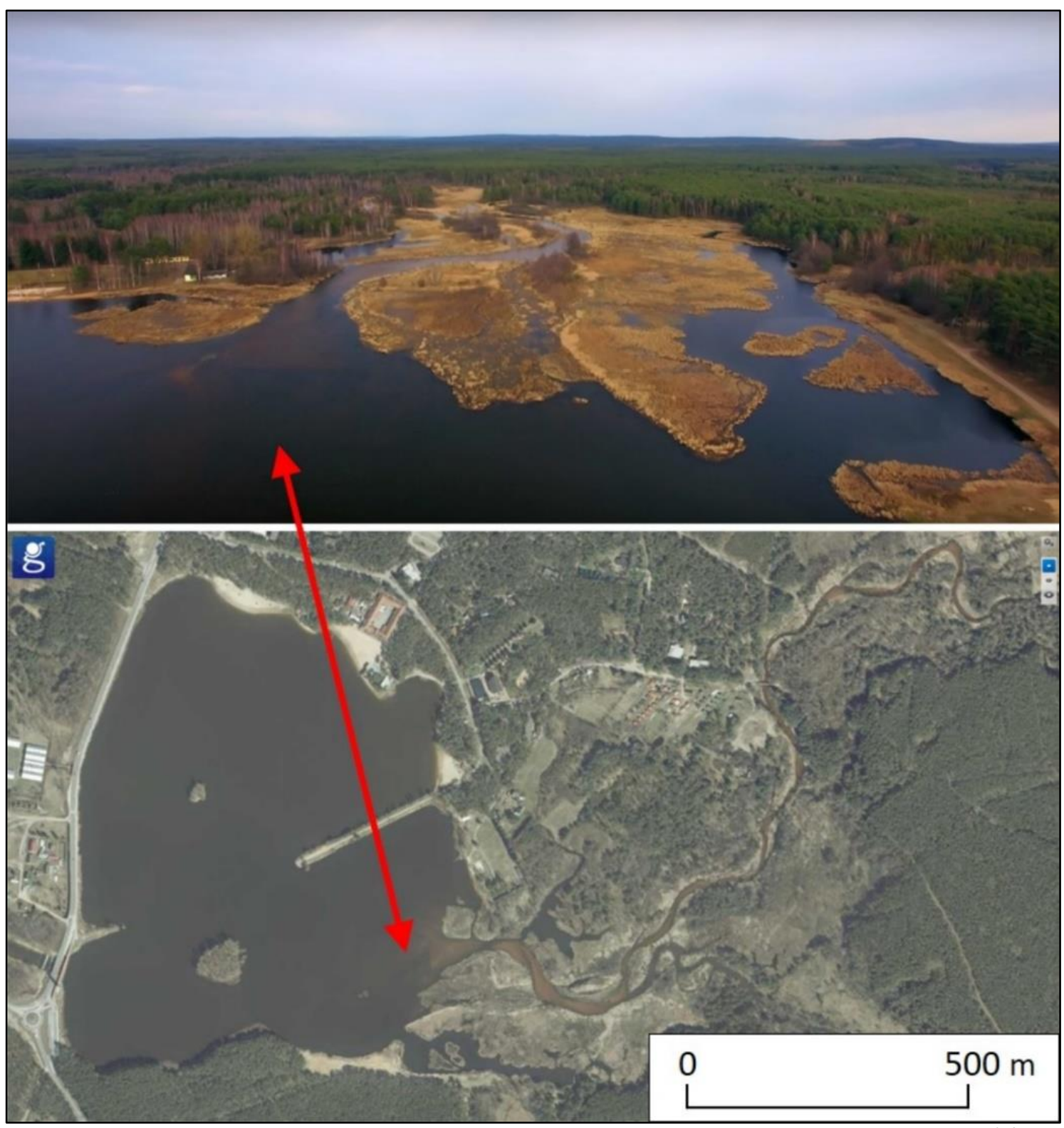

Figure 7. Delta in the mouth of upper Czarna Konecka river to artificial pond at Sielpia Wielka ${ }^{2,3}$ (photo Ł. Wasik 2016) [8]. Estimated depth of the lake in this part is 0.5-0.8 $\mathrm{m}$ [12]

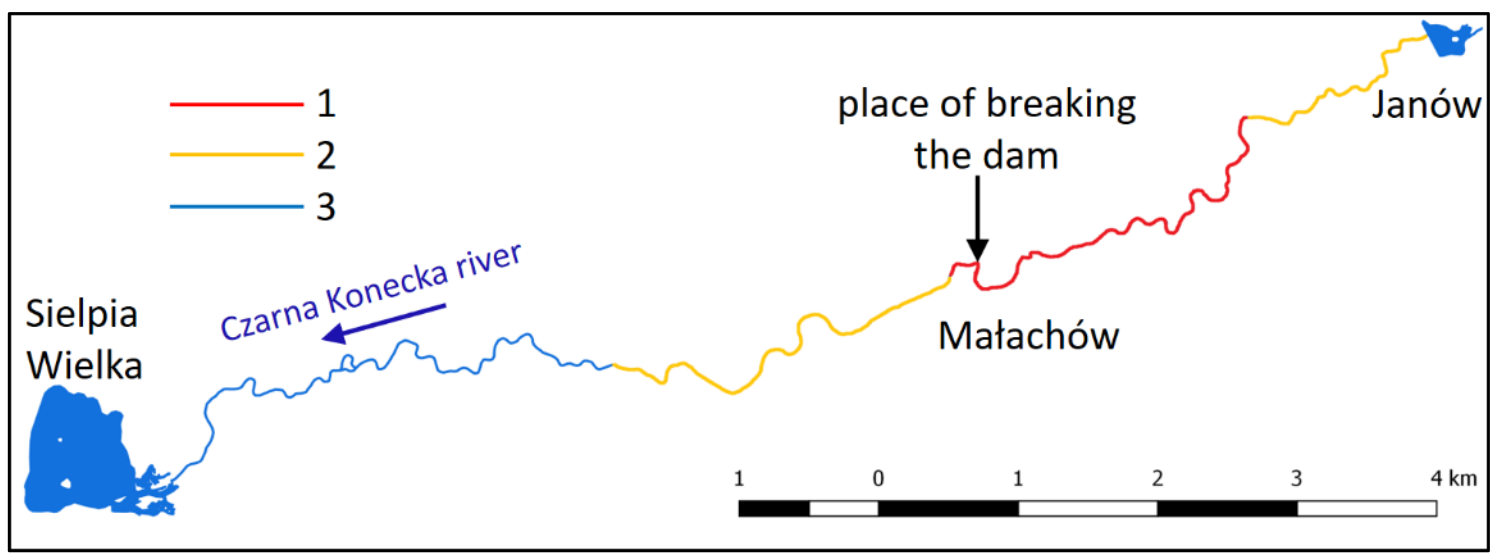

Figure 8. Upper Czarna Konecka river between the reservoirs at Janów and Sielpia Wielka.

Channel sections with intensive incision in 1993-1995 (1) [5] and in 1995-2017 (1,2) and accumulation (3) as a result of the failure of the former dam at Małachów (1993), [8] (prepared on the basis of channel mapping)

\footnotetext{
${ }^{3}$ https://www.youtube.com/watch?v=uwyf3N7go-Q\&index=33\&list=UUqclsFfwvWjip-wxRMNUA2A
} 
Water management of Suchedniów reservoir (Kamionka river) also cause anthropogenic floods (e.g. 2010), that influence a texture of the floodplain alluvia. Grain size analysis of gravel bars on about $300 \mathrm{~m}$ section downstream of the pond indicated the fining sequence of deposits along with an increase distance from the dam (Fig. 9). The finest sediments accumulated on the river bend, where the water speeds is decreasing during water discharge from the lake [9].

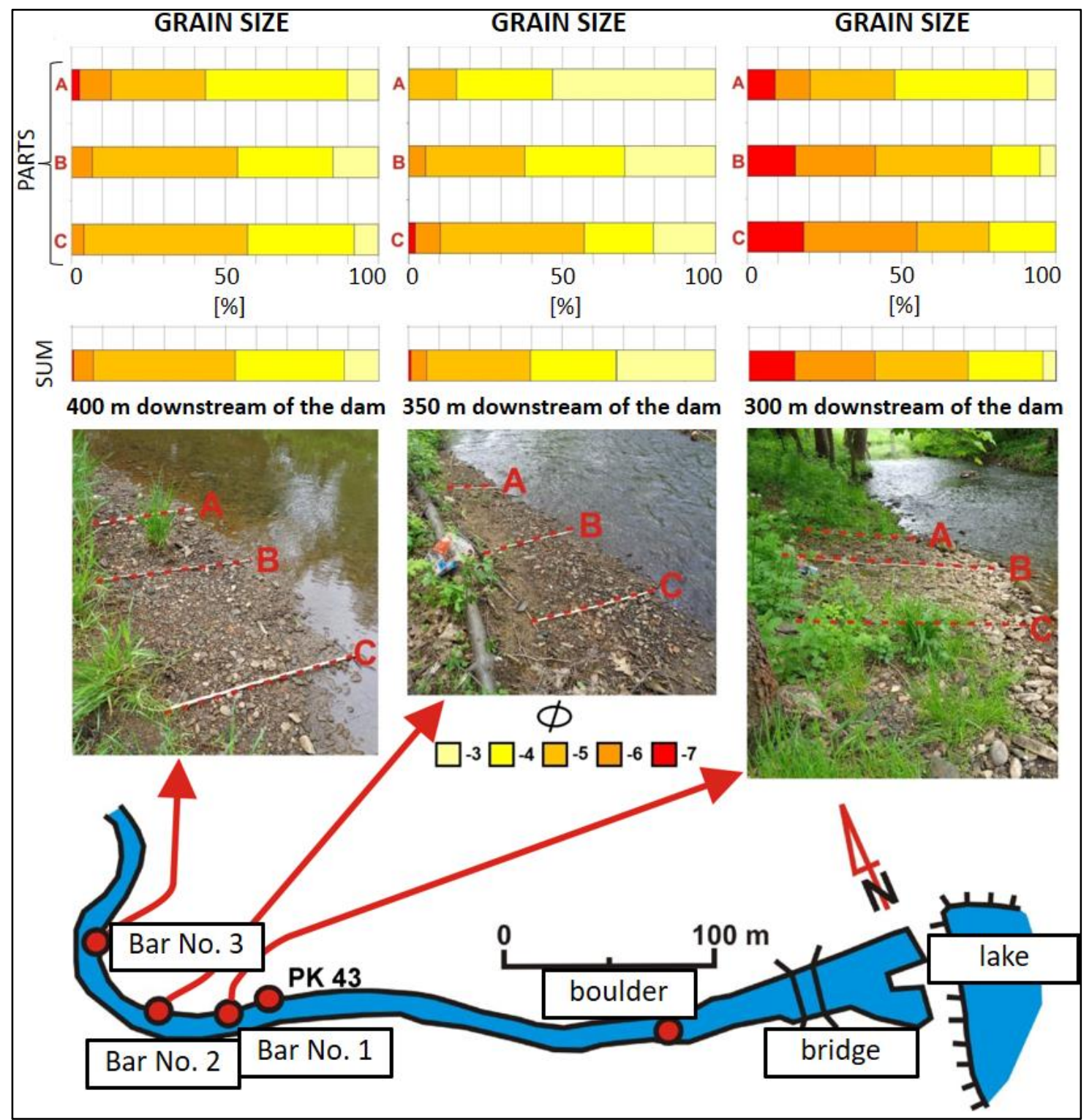

Figure 9. Gravely bars in Kamionka riverbed downstream of the Suchedniów Lake, grain size analyzed based on planimetric method with the location of major objects [8]

\section{DISCUSSION}

At the turn of the $19^{\text {th }}$ and $20^{\text {th }}$ century, the forges activity finally stopped, same as the water mills in the middle of the $20^{\text {th }} \mathrm{c}$.. Some of the ponds were drained and their infrastructure was destroyed. Function of other ponds was changed to floodcontrol and recreation. The anthropogenic small retention constructed since the Middle Age had a beneficial effect on the regulation and speed of water circulation in the catchment. In the $20^{\text {th }} \mathrm{c}$. the technical infrastructure decay was conducive to forming a catastrophic flash floods that was not present in the whole Holocene (no evidence of such events in alluvia and morphology). During the rainy floods there was a break in the shafts and dams that led to rapid drainage of the water reservoir and forming flash floods in the valley downstream of them. This kind of events had occurred many times on the Czarna Konecka and Kamionka river. The geomorphological effects of these floods were very big, surpassing many times the effects of secular processes. These high energy flows determined the cut-fill accumulation of very coarse-grained channel sediments in the sections downstream of the broken dams in those two valleys. Not rebuilt dams in the Czarna Konecka river led to a very intensive incision of the riverbed, resulting in 
confined meanders (Fig. 10) and fix of the single channel pattern [11]. Also flood-control management on the reservoirs cause anthropogenic floods, for example in Suchedniów Lake in 2010.
Those floods forms the coarse grain size of presentday bars and alluvia fining with distance from the dam.

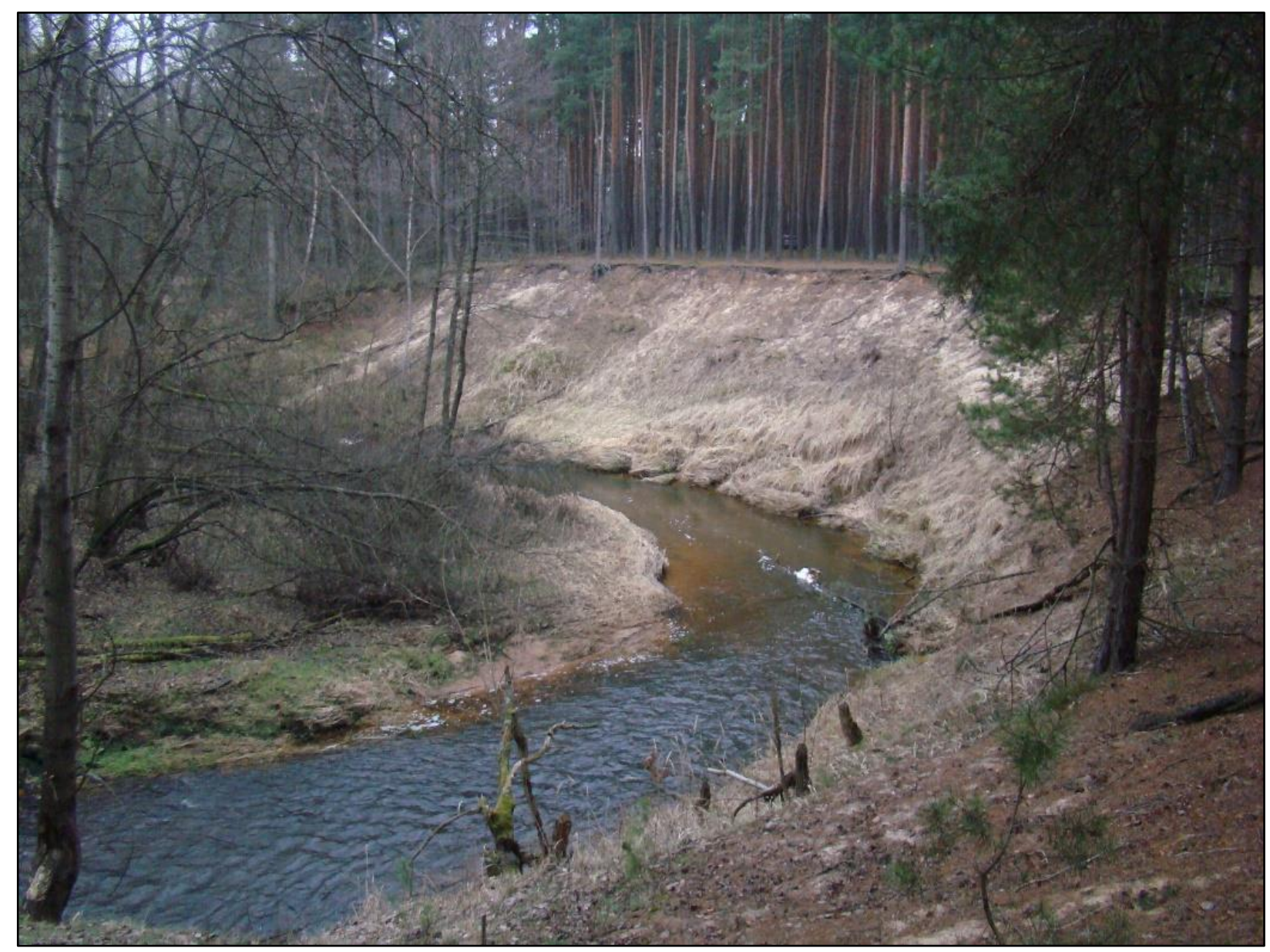

Figure 10. Confined meander of upper Czarna Konecka river (photo 2015)

\section{CONCLUSIONS}

Construction and the subsequent collapse of anthropogenic small retention system led to create catastrophic floods in the valleys of the Holy Cross Mts. region, which had not previously occurred in

the whole Holocene. They have transformed the morphology and alluvia of the flood plains and riverbeds.

\section{ACKNOWLEDGMENTS}

The study was funded by Jan Kochanowski University project BS 612480.

\section{REFERENCES}

[1] Bielenin K. Starożytne górnictwo i hutnictwo żelaza w Górach Świętokrzyskich, Wydanie drugie, poszerzone i poprawione, Kieleckie Towarzystwo Naukowe, pp. 1-267, 1993.

[2] Fajkosz A. (eds.) Wczoraj i dziś stąporkowskich odlewni, CzZG, ZP Kielce, Stąporków, pp. 1-99, 1978.

[3] Nowak S. (eds.) Almanach Świętokrzyski, Stąporków i okolice z historią industrialną w tle, Oficyna Wydawnicza Edward Mitek, Warszawa-Bydgoszcz-Kielce, vol. 2, pp. 1-439, 2017.

[4] Piasta S. Leksykon Suchedniowa, Towarzystwo Przyjaciół Suchedniowa, Kielce, pp. 1-496, 2012.

[5] Kalicki T., Przepióra P., Kusztal P. \& Nowak M. Anthropogenic flash floods on rivers of Holy Cross Mts. region in 20th c. - origin and effects, 3rd Disaster Risk Reduction Conference, Warsaw, 2017, pp. 49.

[6] Wolman M.G. A metod of sampling coarse river - bed material, Am. Geophys. Union Trans., 35, 6, pp. 951-956, 1954.

[7] Pazdur A., Bluszcz A., Stankowski W. \& Starkel L. (eds) Geochronologia Górnego Czwartorzędu w Polsce w świetle datowania radiowęglowego i luminescencyjnego, Wind. Wojewoda J., Wrocław, pp. 1-287, 1999. 
[8] Kalicki T., Przepióra P. \& Kusztal P. Anthropogenic flash floods on rivers of Holy Cross Mts. region in 20th c. origin and effects, Prace i Studia Geograficzne, in print.

[9] Przepióra P. Naturalne i historyczne zmiany zlewni Kamionki (Płaskowyż Suchedniowski) w subatlantyku, Typescript of PhD. degree, Archives UJK, Kielce, pp. 1-140, 2017.

[10] Nowak M.M. Budowa geologiczna i rzeźba doliny Czarnej Koneckiej w rejonie Wąsosza Starej Wsi, Typescript of Msc. degree, Archives UJK, Kielce, pp. 1-103, 2017.

[11] Kalicki T., Frączek M., Przepióra P., Kusztal P., Kłusakiewicz E. \& Malęga E. Overview of the Late Quaternary geomorphological and geoarchaeological research in the Holy Cross Mts. region, Quaternary Research, in print.

[12] Grzyb H., Zięba B., Piotrowicz A. \& Pachołowiecka-Grzyb H. Ekspertyza wraz z koncepcją zabezpieczenia dna rzeki Czarnej Malenieckiej przed erozją i zamulaniem zbiornika w Sielpi (część opisowo-zestawieniowa), Na zlec. WZMiUW w Kielcach, Kielce, pp. 1-33, 1995. 